\title{
Production of Hydrogen and Carbon Nanotubes from Catalytic Decomposition of Methane over Ni:Cu/Alumina Modified Supported Catalysts
}

\author{
Tajammul Hussain, Mohammed Mazhar, Sarwat Jqhal, Sheraz Gul, Muzammil Hussain, and Faical Iarachi

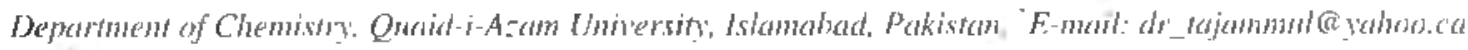 \\ 'Department of Chemical Enginepring, Uniersity of Laval, Quehec, Srimte-Foy, G/K 7P4. Camads \\ Receried Jamuran 18,2007
}

\begin{abstract}
Hydrogen gas and carhon nanotuhes along with nanocarbon were produced from commercial nalurad gas using fixed bed calalyst reactor syctem, The maximum amount of calhon (491 g/g of catalyst) formation was: achieved on 25\% Ni. 3\% Cu supponed catalyst willoul formation of $\mathrm{CO} / \mathrm{CO}_{2}$ Pure carhon nanoluhes with lenglb of $308 \mathrm{~nm}$ having hallonn and horn type shapes were also foj'med at $673 \mathbf{K}$. Three sets of catslysts were prepared by varying the concentration of $\mathrm{Ni}$ in the first sel. Cu concentration in the second sel and doping with $\mathrm{K}$ in the third set to investigate the effect on stahilization of the catalyst and production of carhon nanotuhes and hydrogen by copper and polassium doping. Particle size analysis revealed that most of the calalyst particles are in the range of 20-35 nm. All the catalysts were characterized using powder XRD. SFM/FDX. TPR. CHN BET and CO-chemisompion. Thesc studies indicate that sufface geometry is modified clectronically wilh the formation of different $\mathrm{Ni}, \mathrm{Cu}$ and $\mathrm{K}$ phases, consequently, increasing the sur face reacivity of the calsalys and in turn the Carbon nanotube $/ \mathrm{H}_{2}$ production. The addition of $\mathrm{Cu}$ and $\mathrm{K}$ enhances rhe catalyst dispersion wilh the increase in $\mathrm{Ni}$ loadings and maximum dispersion is achieved on $25 \% \mathrm{Ni}$; $\%$ Cu/Al catalyst. Clearly. Ihe effect of particle size coupled with specific surface geometry on the production of hydrogen gas and carbon nanotuhes prevails. Addition of $\mathrm{K}$ increases the calalyst stahility with decrease in cauhon formation. due to its interaction witl $\mathrm{Cu}$ and $\mathrm{Ni}$. macking $\mathrm{Ni}$ and $\mathrm{Ni}$ Cu actuve sites
\end{abstract}

Key Words : $\mathrm{CH}_{\lrcorner}$decompnsition. $\mathrm{Ni}: \mathrm{Cu} / \mathrm{Al}$ calalysı, Carhon nanotubes, Hydrogen

\section{Introduction}

Catalyuic decomposilion of methane into hydrogen and carbon is of immense present day interest as an altemate source for production ol hydrogen to use it as a clean source of energy. The catalyst used for this purpose is supported nickel. The process of' catalytic decomposition of nafural gas encountered several prohlems that include simultaneous production of $\mathrm{CO}$ and $\mathrm{CO}_{2}$. caralyst deactivalion and particles size effect on the carbon production ${ }^{-1 / 4}$ It is also reporled in the literalure that typical $40 \% \mathrm{Ni} / \mathrm{SiO}_{1}$ catalyst yields carbon as high as $491 \mathrm{gC} / \mathrm{gNi}$ at $773 \mathrm{~K}^{\text {th }}$ Another study indicales that the carhon yield wilh $75 \% \mathrm{Ni}-15 \% \mathrm{Cu} /$ aluimna supported catalysi prepared by co-precipitation method gives a carhon yield of $700 \mathrm{~g} / \mathrm{gNi}$ al $898 \mathrm{~K}$ "The purification (chemical or mechanical) of carbon fiom the catalyst is also quile cumbersome.

To improve the overall efficiency of the process and yield of carbon in the pure form. synlhesis of the catalyst system with controlled particle size antl surface morphologies todale hecomes one of the imporlant areas of $R$ \& $D$ in catalyst developmens. $^{15}$ Various techniques like sole-gel, meralorganic vapor deposition and thermal decomposition used to address the problems suffered a set hack due to agglomeration of material during calcinations. ${ }^{\text {If-Zn }}$ which consequently effects the carbon and hyrlrogen production and results in very fast calalyst deaclivalion.

It has also been reported in the literature thal doping Ni/alumina and Ni/silica catalysts with alkali and alkaline earth melal axides enhances the catalyst slahility and reactivily $^{21-29}$ hecause of the moditication of surface geometry electronically. ${ }^{30-37}$ Again, the agglomeration of particles leads to the deactivation of calalyst resuling in less carbom formalion

In the presenl sludy, carbon ninotubes and hydrogen were produced at low temperature $(67.3 \mathrm{~K}$ ) as compared to that reported in literarure ${ }^{7.4}$ We described a new catalyst preparalion method that enabled us to prepare a catalyst system with controlled particle size and gond metal dispersion which resulted in the producison of pure carhon nanoluhes withoul $\mathrm{CO} / \mathrm{CO}$, production at relatively milal temperature This combolled particle size catalyst when doped with potassium has a significan effect on the catalyst ctahility and reactivily

\section{Experimental}

Calalyst Characterization. X-ray difl'raclion patterns were determined by a Rigaku RINT 2500 V diffractometer using $\mathrm{Cu}-\mathrm{K} \alpha$ radialion at room temperature operated at 40 $\mathrm{kV}$ and $\mathrm{I}(\mathrm{k}) \mathrm{A}$, The mean crystallite sizes of the fresh and spent catalyst samples were calculated using the Scherer equation, where the particle factor was laken as $0.9^{30}$

SFM images and backscattering electoon images of the calalysts were determined using a Hilachi FE-SFM S-800 (field emission gun scanning elecsron micjoscopy)

The $\mathrm{N}_{2}$ adsorplion-desorplion isorhems were ohtained using a Nova 4200 e (Quantachrome) system operated al 77 
$\mathrm{K}$. Before these measurements, all the samples were degassed by vacuum at $573 \mathrm{~K}$ for 5 hours The BET surface area was calculated from the inultipoint BET analysis of nitrogen adsorption isotherm.

The particle size analyses were perfomed using sorptometer KELVIN I042. supplied by COSTECH instruments.

The temperalure programmed reducrion (TPR) was performed in a conventional set up equipped with a thermal conductivity detector (TCD) In a typical run, $50 \mathrm{mg}$ catalyst/catalysts samples were used and heated to $673 \mathrm{~K}(10 \mathrm{~K} /$ min) under Nitrogen flow (40 $\mathrm{mls} / \mathrm{min})$ and kept at this temperature fou 0.5 hours to remove the adsorhed species on the fresh samples. On the spent samples no rreatment was performed. After cooling down to room temperarure the reduction gas ( $\left.20 \mathrm{vol} \% \mathrm{H}_{2} / \mathrm{N}_{2}\right)$ was introduced ( $\left.40 \mathrm{mls} / \mathrm{min}\right)$. The temperalure was then programmed to rise from room temperature to $1073 \mathrm{~K}$ at the ramp of $10 \mathrm{~K} / \mathrm{min}$. CHN analyses were performed on the fresh and spent catalysts using FA1112 (Thenno Electron) equipment.

Catalysts Preparation. Aluminum acetate basic was soaked in $50 \mathrm{~mL}$ of distilled water. $\mathrm{Ni}\left(\mathrm{NO}_{3}\right)_{2} \cdot 6 \mathrm{H}_{2} \mathrm{O}$ and $\mathrm{Cu}\left(\mathrm{NO}_{3}\right)_{2} \cdot 2 \mathrm{H}_{2} \mathrm{O}$ were added to the mixture with constant sturring This slurry was kept soaked at room temperature overnight. The water was evaporated at $120^{\circ} \mathrm{C}$ and kept at this temperature for 12 hours. The dried powder was calcin- ed at $923 \mathrm{~K}$ for six hours. Three sets of catalyst samples were prepared, one keeping the copper concentration conslant and varying the $\mathrm{Ni}$ concentration. the other set in which copper concentration was varied keeping nickel concenIration constant and the third sel of samples was prepared in which nickel and copper concentration were kept constant and porassium concentration was varied Samples of first set were designated as $\mathrm{Ni}: \mathrm{Cu} / \mathrm{A}$ ]: I0:3, Ni:C.u/A]: 15:3, Ni:Cu/ Al: 25:3, the other sel as $\mathrm{Ni} \mathrm{Cu} / \mathrm{Al}: 25: 10, \mathrm{Ni} / \mathrm{Al}: 25 \cdot 75$ and the third sel as Ni:Cu:K/Al. 25:3:0.5, Ni:C.U:K/Al 25:3: I 0 , Ni:C.u:K/Al 25:3:1.5. Polassium doped samples were also prepared using the same procedure described above. The catalyst preparation details and amount of respecrive salts used with the support are presented in Tahle I(a-d). In all the preparations impregnation of metal oxides is hased on the weight percentage of metal nitrates,

Ca1alyst Testing. Methane decomposition over all the prepared catalysts was carried out in the conventional gas flow system. The calalyst loading of $0.5 \mathrm{~g}$ was put at the bottom of the SS reactor with quartz wool at bolh ends. the alumina support was used to hold the catalysi. The sample was reduced in hydrogen flow $(100 \mathrm{mls} / \mathrm{min})$ for 8 -hours at $450{ }^{\circ} \mathrm{C}$. The temperature was then lowered to $400{ }^{\circ} \mathrm{C}$ and methane decomposition was initiated by the contact of stream of methane $\left(\mathrm{P}_{(\mathrm{C}][\mathrm{J})}=100 \mathrm{kP} \mathrm{P}_{\mathrm{in}}\right.$ flow rate $\left.60 \mathrm{mls} / \mathrm{min}\right)$

Tahle I EDX and BET analycis of the proparcd calalyst samples (a)

\begin{tabular}{|c|c|c|c|c|}
\hline Caralyst Designation & $\begin{array}{l}\text { WL of Ni salt used }(\mathrm{g}) / \\
\text { (mmal) }\end{array}$ & $\begin{array}{l}\text { Wi. of Cu sall used }(\mathrm{g}) / \\
\text { (mmnl) }\end{array}$ & $\begin{array}{c}\text { Wr. ol' K sal1 } \\
\text { used }(\mathrm{g}) /(\mathrm{mInol})\end{array}$ & $\begin{array}{l}\text { W. of support (g)/ } \\
\text { (mmol) }\end{array}$ \\
\hline $10 \% \mathrm{Ni} 3 \% \mathrm{Cu} / \mathrm{Al}$ & $24775 / 8.52$ & $0.5703 / 2.36$ & - & $26.1303 / 161.22$ \\
\hline $15 \% \mathrm{Ni} \cdot 3 \% \mathrm{Cu} / \mathrm{Al}$ & $3.7163 / 12.78$ & $0.5703 / 2.36$ & - & $246286 / 151.95$ \\
\hline $25 \% \mathrm{Ni} 3 \% \mathrm{Cu} / \mathrm{Al}$ & $6.1938 / 21.30$ & $0.5703 / 2.36$ & - & $21.6251 / 133.42$ \\
\hline $25 \% \mathrm{Ni}: 10 \% \mathrm{Cu} / \mathrm{Al}$ & $6.1938 / 21.30$ & $1.9010 / 7.87$ & - & $19.5226 / 120.45$ \\
\hline $25 \% \mathrm{Ni} / 75 \% \mathrm{Al}$ & $6.1938 / 21.30$ & - & - & $22.5261 / 138.98$ \\
\hline $25 \% \mathrm{Ni}-3 \% \mathrm{Cu} .9 .5 \% \mathrm{~K} / \mathrm{Al}$ & $6.1938 / 21.30$ & $0.570 .3 / 2.36$ & $001646 / 064$ & $21.4749 / 132.50$ \\
\hline $25 \% \mathrm{Ni} .3 \% \mathrm{Cu}: 1.0 \% \mathrm{~K} / \mathrm{Al}$ & $6.1938 / 21.30$ & $0.5703 / 2.36$ & $0.1293 / 128$ & $213247 / 131.57$ \\
\hline $25 \% \mathrm{Ni} .3 \% \mathrm{Cu}: 1.5 \% \mathrm{~K} / \mathrm{Al}$ & $6.1938 / 21.30$ & $0.5703 / 2.36$ & $01939 / 192$ & $211746 / 130.64$ \\
\hline
\end{tabular}

(h) Sel No. I

\begin{tabular}{cccc}
\hline Caldalya Designation & $\% \mathrm{Cu}$ & $\% \mathrm{Ni}$ & ${\text { Surface area } \mathrm{m}^{2} \mathrm{~g}^{-1}}$ \\
\hline $10 \% \mathrm{Ni}: 3 \% \mathrm{Cu} / \mathrm{Al}$ & 292 & 9.3 & 141 \\
$15 \% \mathrm{Ni}: 3 \% \mathrm{Cu} / \mathrm{Al}$ & 290 & 14.1 & 1.52 \\
$25 \% \mathrm{Ni}: 3 \% \mathrm{Cu} / \mathrm{Al}$ & 296 & 24.3 & 196 \\
\hline
\end{tabular}

(c) Sel No 2

\begin{tabular}{cccc}
\hline Calkalyst Designation & $\% \mathrm{Ni}$ & $\% \mathrm{Cu}$ & Surface $\operatorname{arca}^{2} \mathrm{~m}^{1} \mathrm{~g}^{-1}$ \\
\hline $25 \% \mathrm{Ni} / \mathrm{Al}$ & & 23.9 & 112 \\
$25 \% \mathrm{Ni}=10 \% \mathrm{Cu} / \mathrm{Al}$ & 23.78 & 8.79 & 90 \\
\hline
\end{tabular}

(d) Sel No 3

\begin{tabular}{|c|c|c|c|c|}
\hline Calalyst Designation & $\mathscr{C} \mathrm{Ni}$ & $\% \mathrm{Cu}$ & $\mathscr{F} \mathbf{K}$ & Surface arca $\mathrm{m}^{2} \mathrm{~g}^{-1}$ \\
\hline $25 \% \mathrm{Ni}: 3 \% \mathrm{Cu} 05 \% \mathrm{~K} / \mathrm{Al}$ & 247 & 2.92 & 0.41 & 87 \\
\hline $25 \% \mathrm{~N} 13 \% \mathrm{Cu}-0 \% \mathrm{~K} / \mathrm{Al}$ & 2398 & 2.90 & 0.90 & 78 \\
\hline $25 \% \mathrm{Ni} 3 \% \mathrm{Cu} 1.5 \% \mathrm{~K} / \mathrm{Al}$ & 2396 & 2.95 & 1.34 & 69 \\
\hline
\end{tabular}


with the catalyst During methane decomposition, part of stream gases of the catalyst bed was sampled and analyzed hy GC. Conversion of methane was evaluated from the amount of hydrogen formed, assuming that the reaction, $\mathrm{CH}_{\lrcorner} \rightarrow \mathrm{C}+2 \mathrm{H}_{2}$, proceeded selecilively. In fact, hydrogen and unreacled $\mathrm{CH}_{4}$ were confirmed as gaseous products during the reaction.

Tahle 1. shows the \%age composition of all the catalyst samples for $\mathrm{Ni}, \mathrm{Cu}$ and $\mathrm{K}$ and the AFT surface area. l1 can be seen from Table 1(a-c) that atomic \%ages of Ni, C.u and $\mathrm{K}$ determined after prepararion of the catalyst agree well with the theoretical values confirming that the preparation procedure we adopted results in the maximum coaling of the $\mathrm{Ni}$, $\mathrm{Cu}$ and $\mathrm{K}$ on to the support Consequently. any change in the caltalyst activity and selectivity reported in this article is due to surface modification by $\mathrm{Cu}, \mathrm{K}$, and parlicle size rather than the inhomogeneous deposition of $\mathrm{Ni}$. Cu and $\mathbf{K}$ on to the support.

\section{Results and Discussions}

\section{Catalyst Characterization}

Catalyst Characterization Using XRD. Figure I shows the XRD patterns of the samples, fresh and spent. All the fresh and spent samples showed a rypical face centered cubic structure. This is an indication that carbon nano tubes formation on the spent catalyst does not effect the phase of the macerial. A consistent decrease in the intensity of melal oxides' peaks is nhserved with an increase in Nickel loadings in comparison with parent Nickel sumple, which reveals modification in the catalys geometry.

The particle size showed a marked decrease on the spent catalyst, clearly indicating the formation of carbon nano particles (Table 2). The surface morphologies of $\mathrm{Cu}$ and $\mathrm{K}$ doped samples showed a marked change due 10 surface modification electronically of the calalyst resulting from addition of $\mathbf{K}$, consequently modifying the textural proper-

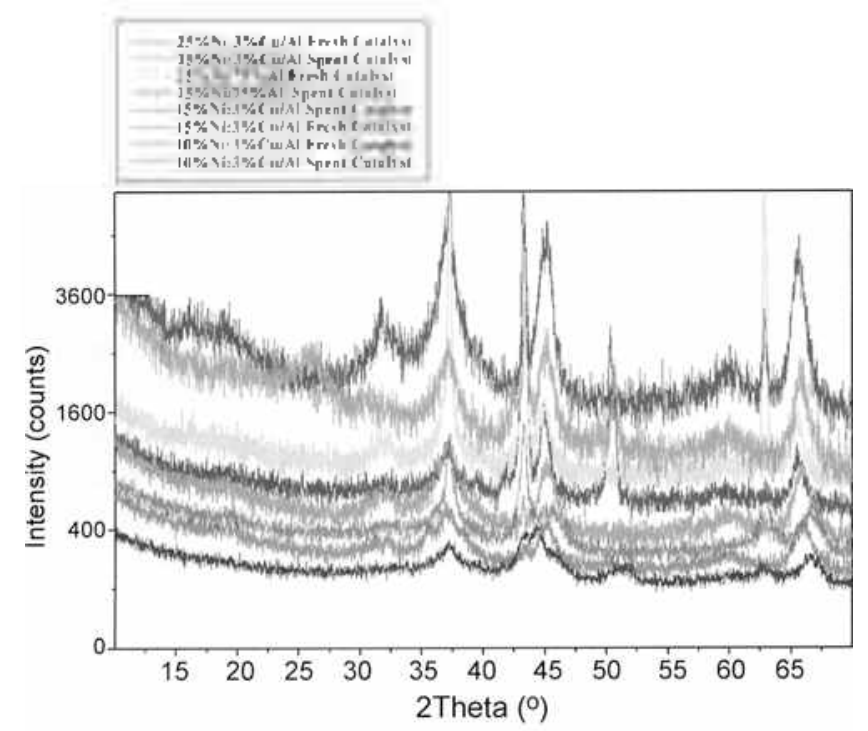

Figure 1. XRD analysis of the prepared catalyst samples.
Tahle 2. Estimation of crystallite sige using XRD data

\begin{tabular}{ccc}
\hline Caralyst Designation & Fresh $(1 \mathrm{~mm})$ & Spent $(\mathrm{nm})$ \\
\hline $10 \% \mathrm{Ni}: 3 \% \mathrm{Cu} / \mathrm{Al}$ & 302 & 17.95 \\
$15 \% \mathrm{Ni}: 3 \% \mathrm{Cu} / \mathrm{Al}$ & 346 & 20.02 \\
$25 \% \mathrm{Ni}: 3 \% \mathrm{Cu} / \mathrm{Al}$ & 256 & 13.6 \\
$25 \% \mathrm{Ni} .10 \% \mathrm{Cu} / \mathrm{Al}$ & 32.98 & 18.09 \\
$25 \% \mathrm{Ni}: 3 \% \mathrm{Cu} .1 \% \mathrm{~K} / \mathrm{Al}$ & 4466 & 3794 \\
$25 \% \mathrm{Ni} / \mathrm{Al}$ & 29.25 & 11.54 \\
\hline
\end{tabular}

ries of the catalysts. The addition of $\mathbf{K}$ does not appreciably effect the particle size. this gives support to our aroument thac the addition of $\mathrm{K}$ electronically modified the surface geometry, and the particle size effect on $\mathrm{K}$ doped sample is suppressed by the electronic modification of surface by $\mathrm{K}$ addition, thus the carhon formation on $\mathrm{K}$ doped sample is reduced quite substantially.

Table 3 shows the amount of $\mathrm{CO}$ adsorbed on the catalyst semples. The amount decreases on the spent caralysts and on $\mathrm{K}$ doped samples indicating the surface coverage of catalyst by carbon and potassium. As the Ni concentration increases the amount of $\mathrm{CO}$ adsorhed on the fresh catalyst samples increases, an indication of modified surface geometry This is supported by SEM where carbon formation increases with the increase in Ni concentration.

The surface weighted average parlicle sizes of the promoted and umpromoted catalysts were roughly estimated from CO-chemisorption to be in the range of $1600 \mathrm{~nm} 1030.00$ $\mathrm{nm}$ on fresh samples indicating good agreement with the values obrained from XRD. The Ni surface areas of all the catalyst samples were calculated using the following equation.

$$
D_{p}(\mathrm{n} \mathrm{m})=101 / D
$$

The dispersion of the catalyst system having $25 \% \mathrm{Ni}$ : $3 \% \mathrm{Cu} / \mathrm{Al}$ was found to be the maximum as indicated in Tahles 3 and 4 . This indicates that the modified procedure adopted in the preparation of catalysts gives a high dispersinn of Ni on the surface of the calalyst in comparison with the conventional methods used to date.

The coverage of $\mathrm{Ni}\left(\theta_{K}\right)$, by $K_{1}$ was calculated from the CO adsomption data. CO chemisorption results (Table 3) showed a substantial decrease in Ni coverage on the $\mathrm{K}$ doped samples indicaling that $\mathrm{K}$ addition masked the emission of $\mathrm{Ni}$ We suggest here that due to this modification in the malerial characteristics, $\mathbf{K}$ addition hes direct effect on the fonmalion of CNT"S/NC and also on the stability of the catalysts during $\mathrm{CH}_{4}$ decomposition.

The active Ni surface area per gram of catalyst, as esilmated using $\mathrm{CO}$-chemisorption and $\mathrm{Ni}$ atom area $(6.5 \times$ $10^{-20} \mathrm{~m}^{2}$ alnm ${ }^{-1}$ ), was $2.6-6.1 \mathrm{~m}^{2} \mathrm{~g}-\mathrm{cat} .^{-1}$.

Catalyst Characterization Using Temperalure Programmed Reduction (TPR). Figure 2 illustrates the $\mathrm{H}_{2}$ TPR profile of the catalyst samples (fresh). The figure shows a hroad peak around $400{ }^{\circ} \mathrm{C}$ representing the characteristic reduction of $\mathrm{Ni}: \mathrm{Cu}$. Jenkins ef al. showed the TPR-H reduction peaks around $360{ }^{\circ} \mathrm{C}$, which they assigned to the characteristic reduction of stiochiometric nickel oxide. ${ }^{\text {th }}$ In 
Table 3, Characlenzalion of caldyst samples using selective CO-chemisorption

\begin{tabular}{|c|c|c|c|c|c|}
\hline Catalyst Designation & $\begin{array}{c}\text { Ni crysiallite size } \\
\text { (1m })\end{array}$ & $\begin{array}{l}\text { CO-adsorption } \\
\left(\mu \text { molg }{ }^{-1}\right) \text { (Fresh) }\end{array}$ & $\begin{array}{l}\text { CO-adsorption } \\
\left(\mu \mathrm{molg} \mathrm{g}^{-1}\right) \text { (Sрель) }\end{array}$ & $\begin{array}{l}\text { Ni Coverage } \\
\left(\theta_{\mathrm{K}}\right) \text { (Fresh) }\end{array}$ & $\begin{array}{c}\% \mathrm{Ni} \\
\text { Dispeı sion }\end{array}$ \\
\hline $10 \% \mathrm{Ni} \cdot 3 \% \mathrm{Cu} / \mathrm{A} \mid$ & 24.39 & 98 & 8.3 & 0.33 & 41 \\
\hline $1.5 \% \mathrm{Ni} \cdot 3 \% \mathrm{Cu} / \mathrm{A} \mid$ & 20.83 & 110 & 90 & 0.42 & 49 \\
\hline $25 \% \mathrm{Ni}: 3 \% \mathrm{Cu} / \mathrm{Al}$ & 1639 & 123 & $|n|$ & (1) 58 & 61 \\
\hline $25 \% \mathrm{Ni} \cdot 10 \% \mathrm{Cu} / \mathrm{Al}$ & 26.31 & 112 & 100 & 0.49 & 38 \\
\hline $25 \% / \mathrm{Ni}: 3 \% \mathrm{Cu}:|\% \mathrm{~K} / \mathrm{A}|$ & 38.46 & 90 & 82 & 0.20 & 26 \\
\hline $25 \% \mathrm{Ni} / \mathrm{Al}$ & 30.33 & $80)$ & 73 & 0.10 & 3.3 \\
\hline
\end{tabular}

Tahle 4. Fstimation of $\%$ age Ni dispersion using the particle size calculated from XRD dati

\begin{tabular}{ccc}
\hline Calalyst Designalion & $\begin{array}{c}\text { Fage Ni dispersion } \\
\text { Fresh }\end{array}$ & $\begin{array}{c}\text { \% ine Ni di<persion } \\
\text { Spent }\end{array}$ \\
\hline $10 \% \mathrm{Ni} \cdot 3 \% \mathrm{Cu} / \mathrm{Al}$ & 3.34 & 5.63 \\
$1.5 \% \mathrm{Ni} \cdot 3 \% \mathrm{Cu} / \mathrm{Al}$ & 2.92 & 5.04 .5 \\
$25 \% \mathrm{Ni} \cdot 3 \% \mathrm{Cu} / \mathrm{Al}$ & 3.94 & 7.43 \\
$25 \% \mathrm{Ni}: 10 \% \mathrm{Cu} / \mathrm{A}]$ & 3.06 & $5.5 \%$ \\
$25 \% \mathrm{Ni}: 3 \% \mathrm{Cu} / \mathrm{I} / \mathrm{K} / \mathrm{Al}$ & 2.26 & 4.63 \\
$25 \% \mathrm{Ni} / \mathrm{Al}$ & 3.45 & 3.78 \\
\hline
\end{tabular}

our case the peak is slightly higher. indicaling the surface modification and formation of $\mathrm{Cu}: \mathrm{Ni}$ bimelallic $\mathrm{As}$ the $\mathrm{Ni}$ concentaation in the sample increases nol only the reduction peak is shifted to higher temperature hut also it spliss into Iwo distinct peaks onc indicating the NiO reduction and the other representing the reduction of $\mathrm{Ni}$ :Cu himetallic. For $\mathrm{K}$ doped samples the reduclion peak shifted to higher lemperatue, an indication of electronic effect due to addilion of $\mathrm{K}$. Alıhough, $\mathrm{K}$ doped samples huve a different particle size and particle shape. they exhibiled similar reduction fearures wilh slrong hydrogen reduction peaks from $360-500^{\circ} \mathrm{C}$. The procedure we have adopled in the preparation of confrolled size parlicle supports the above ohservation and we sugges that $\left.\mathrm{A}\right|^{\text {i.t }}$ is incorporated into the Ni:C.u frame work and inhihits the crystal growth during the $\mathrm{CH}_{\lrcorner}$decomposition reaction. This probahly makes the $\mathrm{Ni}$ reduction easy The TPR profile of the systems supports our findings. XRD and TPR data suggest that an appropriate value of $3 / 1$ exists in the $\mathrm{Ni} / \mathrm{Al}$ ratio which may he the basic reason for the fommation of highly dispersed NiC. C. Al catalysts. The highest reduction temperalures are ohserved for $25 \% \mathrm{Ni} 3 \% \mathrm{Cu} / \mathrm{Al}$ catalyst, which alan shows that the hest dispersion can only be achieved up in $25 \% \mathrm{~N}$ concentration It is concluded that the effect of Ni hydrotalcite affords a subsiantial elfect on the formation of highly dispersed catalyst ( on the higher concentration of Ni this structure is lost and this is the reason that the dispersion of catalyst reduces on higher $\mathrm{Ni}$ loaded samples. We also propose here that the formation of $\mathrm{Ni}$-Aluminates also contributes to the increase in reduction temperalure with the jncrease in Ni loading and conseguently the catalyst dispersion and reactivity of the catalysts This is supported by XRD data where the NiAluminates are formed on higher loaded Ni catalyst samples thatn $25 \% \mathrm{Ni}$ l1 musl also he noted that the formation of $\mathrm{Ni}^{+2}$

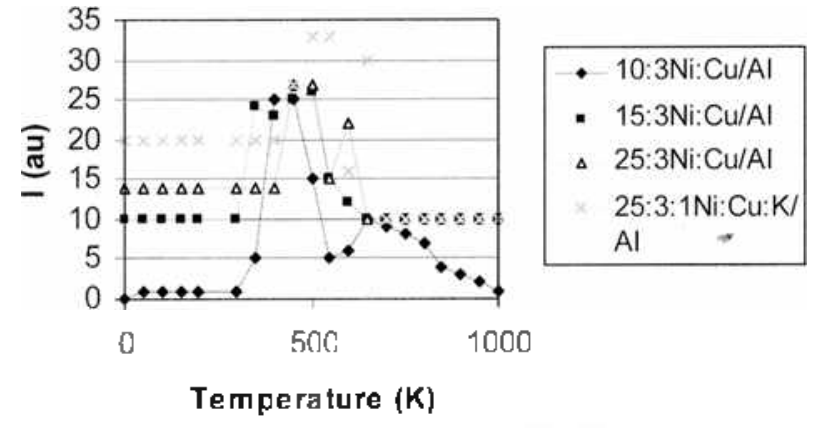

Figure 2. $\mathrm{H}_{2}$-TPR profile of Ni:Cu/Al \& Ni.Cu: K/Al samples.

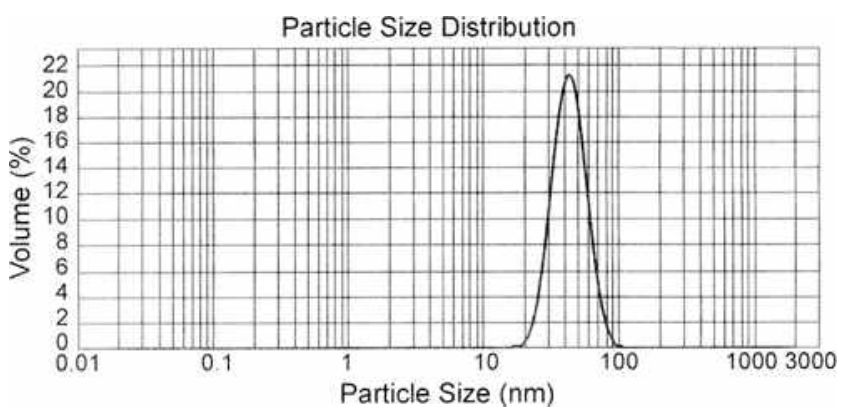

Figure 3. Parlicle size andysis of $25 \% \mathrm{Ni}: 3 \% \mathrm{Cu} / \mathrm{Al}$ sample.

is controlled hy the incorporation of $\mathrm{Al}^{3+}$ during the preparation which controls the dispersion and phase change paramelers,

XRI) observalion of the catalyst samples after the reaclion showed not only the change in the angle ol diffraction hut also an appreciahle chonge in particle sizc suggesting the formation of nano carhon particles and also the change in surface morpholngy of the catalysts. This is also supporled by the CHN analysis reported in Tahle 6. where maximum carbon/carbon tuhes formation is ohserved on the $25 \% \mathrm{Ni}$. $3 \% \mathrm{Cu} / \mathrm{Al}$ sample.

Particle Size and Morpholngy of the Catalyst Systems. Particle size analysis of our most effective sample is shown in Figure 3. This is good indication of the preparation of contiolled particle size catalysts used in the present study.

From the reaction results of methane decomposition. it seems that the initial particle size and mophology of nickel catalysts had an important effect on the calalycic performance. We propose here. hased on our XRD results, that on the spent catalysts average particle size decreases in comparison with the fresh sample. This is pointing out the formation of graphitic type of carbon (less reactive carbon). 


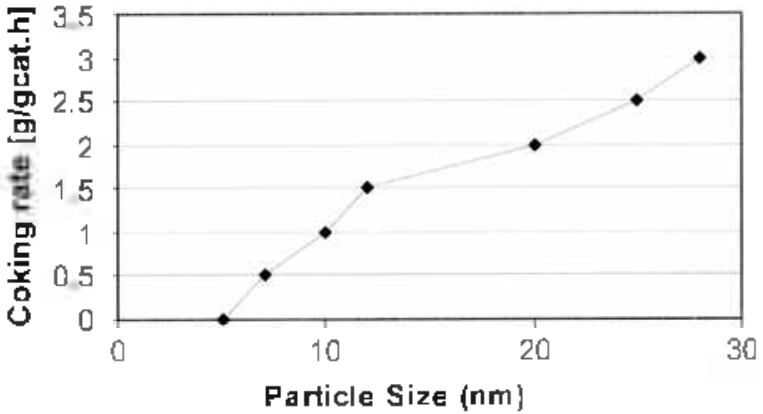

Fignre 4 Fffecl of parlicle cize on the coking threshold. $25 \% \mathrm{Ni}$ : 3\% $\mathrm{Cu} / \mathrm{Al}$ catalysij.

Rostrup-Nielson, ${ }^{* 1}$ on the hasis of theoretical sludies, pointed out that the smaller the particle size, closer will he the thermodynamic properties to graphite, which yields a high coking threshold. On the hasis of this algument. the effect of Cu becomes more pronounced, which though yields substantial amount of carhon hut the presence of Cu prevents the formation of reactive type of carhon and in turn no $\mathrm{CO}$ and $\mathrm{CO}_{2}$ is produced.

The value of the coking threshold during methane decon. posilion can he extrapolated from the curve shown in Figure 4. The coking threshold is 3.0 on $28 \mathrm{~nm}$ Ni crystals, whereas it is about $1.5 \mathrm{mn} 12 \mathrm{~mm} \mathrm{Ni}$ crysials. This also supports our argument that the particle size coupled with C.u interaction has a well defined effect on our samples.

Mechanism of Formation of CN Fihers/Tubes. It has been generally accepled that the mechanism of formation of CNF/T includes the adsorprion of disintegraled carhon from hydrowarhons via catalylic surface reacions, subsequent segregalion of surface cabon into layers near the surface. diffusion of carbon through $\mathrm{Ni}$ and then precipitation on the rear side of the Ni particle The process will lead to the formation of CNF/T, as presented in the following equalions.

$$
\begin{aligned}
& \mathrm{CH}_{1}+2 \mathrm{~S}=\mathrm{CH}_{3} \mathrm{~S}+\mathrm{H} \cdot \mathrm{S} \\
& \mathrm{CH}_{2} \mathrm{~S}+\mathrm{S}=\mathrm{CH}_{2}-\mathrm{S}+\mathrm{H}-\mathrm{S} \\
& \mathrm{CH}_{2} \mathrm{~S}+\mathrm{S}=\mathrm{CH}-\mathrm{S}+\mathrm{H}-\mathrm{S} \\
& \mathrm{CH}-\mathrm{S}+\mathrm{S}=\mathrm{C}-\mathrm{S}+\mathrm{H}-\mathrm{S} \\
& 2 \mathrm{H}-\mathrm{S}=\mathrm{H}_{2}+2 \mathrm{~S}
\end{aligned}
$$

Dissolution/Segregation

$$
\mathrm{C}-\mathrm{S}=\mathrm{C}_{\mathrm{Ni}, \mathrm{f}}+\mathrm{S}
$$

Diffusion of carbon through Nickel

$$
\mathrm{C}_{\mathrm{X} \mathrm{i}, \mathrm{l}} \rightarrow \mathrm{C}_{\mathrm{N}, \mathrm{r}}
$$

Precipitation/dissolution of carbon

$$
\mathrm{C}_{\mathrm{Ni}, \mathrm{r}}=\mathrm{C}_{\mathrm{I}}
$$

Encapsulating carbon formation:

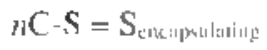

where $\mathrm{S}$ is the adsorplion site: $\mathrm{C}_{\mathrm{Ni} .1}$ is the carbon dissolved in nickel at the front of the parlicle. just helow the selvage; $\mathrm{C}_{\mathrm{Ni}, \mathrm{r}}$ is the carbon dissolved in nickel at the rear side of the

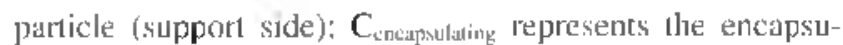
lating cabon formation on the Ni surface, which deactivates the calalysts; and $n$ is the ensemble size.

The yield of CNFs/CNTs depends on the initial coking rate and on the deactivation rate. In principal, high initial coking rates combined with low deactivation rate wil] result in high yields of CNFs/CNTs. Based on the SEM image presented in Figure I0 and XRD results presented in Figure 11 for $\mathrm{K}$ doped samples, it could he concluded that maximum yield of CNFs/CNTs can he ohtained on a Ni crystal size of about $28 \mathrm{~nm}$.

However, it could be argued thal support may have effects, other than $\mathrm{Ni}$ crystal size, on the coking rale and on the deacrivation. The effect of support on the formation CNFs/ CNTs has been studied widely. ${ }^{-12}+1.1$ Mosl of the studies have focused on the effect of support on the diameler and the distribution of CNFs as well as on their morphology-Colin Park and Mark A. Keane ${ }^{+4}$ sludied $\mathrm{Ni}$ as catalyst and $\mathrm{Al}_{2} \mathrm{O}_{1}$, $\mathrm{MgO}, \mathrm{SiO}_{2}$ and $\mathrm{Ta}_{2} \mathrm{O}_{2}$ as support materials for the production of C.NFs. They found out that the support influenced not only the diameter of CNFs but also the density of CNFs as ohserved in SEM images, which were used as an index of CNF yield.

In the presenl study we have found that the preparation procedure of the catalysts we have adopled, gives a very narrow hand of particle size, the particle size and the probahility of carbon growth is presented in Fignre 5 and the maximum growth of CNTs occuned in the range of 25-30 nm particle size which amounts to be $48-50 \%$ carhon production as presented in EDAX analysis (Figure 7 and Table 5) and CHN analysis reported in Tahle 6, The CNTs oblained from Ni nanoparticles with the average rliame!er of 25-30 nm have lengll of $318.0 \mathrm{~mm}$ (Figure 8). The striking leature of this study is the production of single tube of nano carbon and very pure ton. Such CNTs can direculy be sued for hydogen storage without any further treatment, This study will be presented else where.

Based on our SEM findings, the amorphous nature of CNTs is quite evident and is very high Another important feature is the formation of hallom and horn type CNTs which have considerable large lenglh and dianele. This can he attribuled to the presence of copper in the sample which produces sites responsible for the formation of amorphous CNTs. No other form of carbon is formed and it is supported

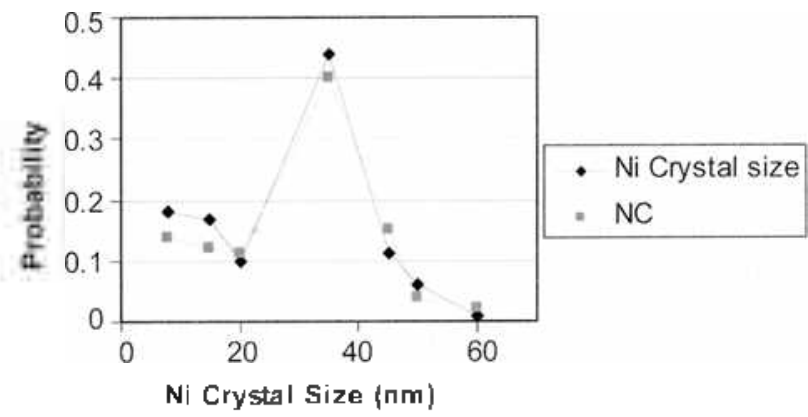

Figure 5. Effect of Particle size on cubon growh (calalyst 25\% Ni: $3 \% \mathrm{Cu} / \mathrm{Al})$ 
(a)
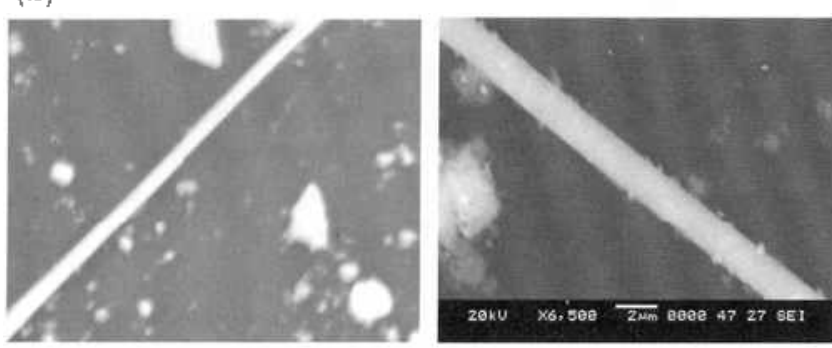

(b)
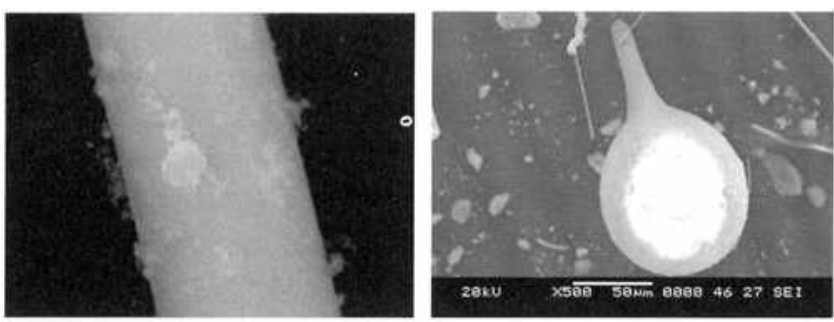

(c)

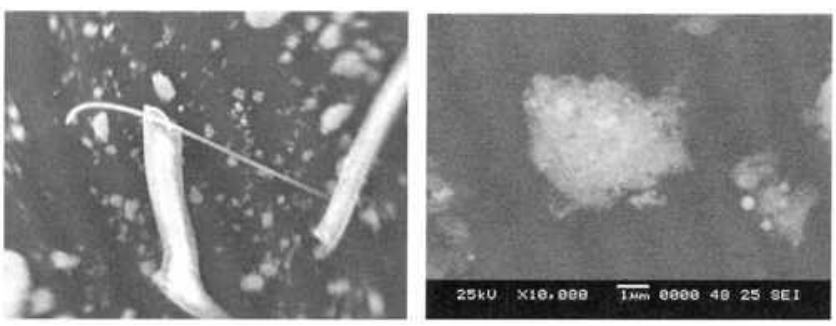

Figure 6 , (a) SEM analysis of $10 \%$ and $15 \% \mathrm{Ni} 3 \% \mathrm{Cu} / \mathrm{Al}$ catalyst (h) SFM analycis of $25 \% \mathrm{Ni} 3 \% \mathrm{Cu} / \mathrm{Al}$ calalyst showing purc and balloon Iype CNTs production. (c) SFM analysis of $25 \% \mathrm{Ni} 3 \% \mathrm{Cu}$ Al calalyst showing horn lype CNTs and $25 \%$ Ni: $75 \%$ Al catalyst showing tormation of nano carbon only.

by XRD results, meaning that rather high purity CNTs are formed This is partially duc to low temperature used for the reaction hut mainly due to presence of $\mathrm{Cu}$. The low temperalure avoids carhon deposilinn by gas phase reaction. The results of catalytic studies indicate that no $\mathrm{CO}$ and $\mathrm{CO}$. are formed. so the hydrogen produced in the present study is rather very pure,

Calalysts Characterization Using SEM. Figure f(a-g) shows the SFM images of carbon nanotubes formed on different $\mathrm{Ni}$ loading samples after methane decomposition. As the Ni concentration increases the diameter of the CNTs increases. On the $25 \% \mathrm{Ni}: 3 \% \mathrm{Cu} / \mathrm{Al}$ samples where maximum activity of the catalyst is observed, nanotubes with diameter of around 20-25 nom are fomed and curbon in the nanotuhes 1s aligned along the rube axis. The shape of the Ni particles present is mainly homogeneous with hollow struclure. We are producing the straight, balloon and horn like carbon nanotuhes which is an indicarion that carbon nanotubes of designed size and dimensions could be formed by the conirol of reaction temperature and particle size,

The F.fTect of K Doping on the Iecomposition of $\mathbf{C} . \mathrm{H}_{\downarrow}$. Figures I0, I I and Table 7 present the SEM, XRD and FDX analyses of the $\mathrm{K}$ doped fresh and spent samples. Two

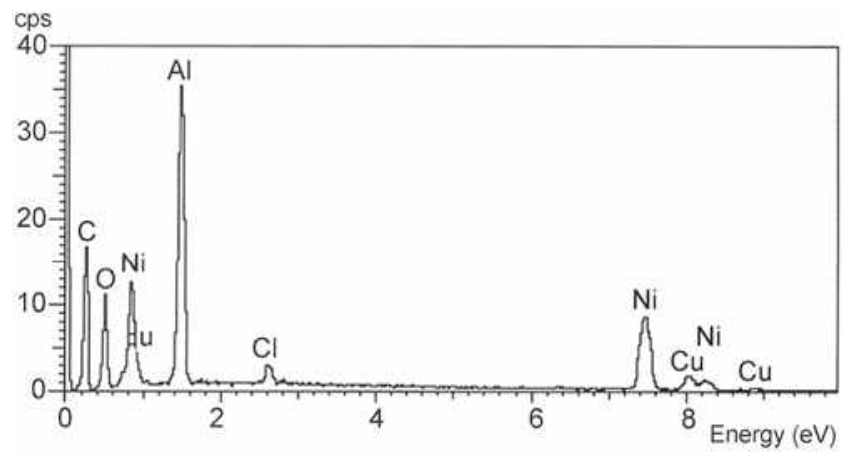

Figure 7. FDAX analysis of the $25 \% \mathrm{Ni} 3 \% \mathrm{Cu}$ atter $\mathrm{CH}_{\downarrow}$ decomposicion.

Table 5. Results of EDX Analysis (contenls in weiglıt percen1)

\begin{tabular}{|c|c|c|c|c|c|c|c|}
\hline Sample & & C. & 0 & $\mathrm{Al}$ & $\mathrm{Cl}$ & $\mathrm{Ni}$ & $\mathrm{Cu}$ \\
\hline $\begin{array}{l}25 \% \mathrm{Ni}: 3 \% \mathrm{Cu} / \mathrm{Al} \\
\text { Fresh }\end{array}$ & Mean & 0.0 & 42.1 & 26.8 & 2.7 & 2.1 .6 & 49 \\
\hline $\begin{array}{l}25 \% \mathrm{Ni} \cdot 3 \% \mathrm{Cu} / \mathrm{Al} \\
\text { Ijeel }\end{array}$ & Mean & 48.1 & 22.9 & 11.5 & 0.7 & 13.8 & 3.0 \\
\hline
\end{tabular}

Tahle 6. CHN analysis of $25 \% \mathrm{Ni}: 3 \% \mathrm{Cu} / \mathrm{Al}$ cpenl calalys

\begin{tabular}{|c|c|c|c|c|}
\hline $\begin{array}{l}\text { Componens } \\
\text { Name }\end{array}$ & $\begin{array}{l}\text { Retentinn Time } \\
\text { (min.) }\end{array}$ & $\begin{array}{c}\text { Area } \\
\left.\text { (.) } \text { uV* }^{*} \mathrm{Sec}\right)\end{array}$ & $\begin{array}{l}\text { Element } \\
\text { amounl }\end{array}$ & $\begin{array}{c}\text { Elemen! } \\
\%\end{array}$ \\
\hline Nilrngen & 0.783 & 1958181 & 0.060 & 2.404 \\
\hline Cartion & 1.200 & 59707440 & 1.289 & .51.386 \\
\hline Hydrogen & 3.550 & $23224360)$ & 0.1 .56 & 6236 \\
\hline
\end{tabular}

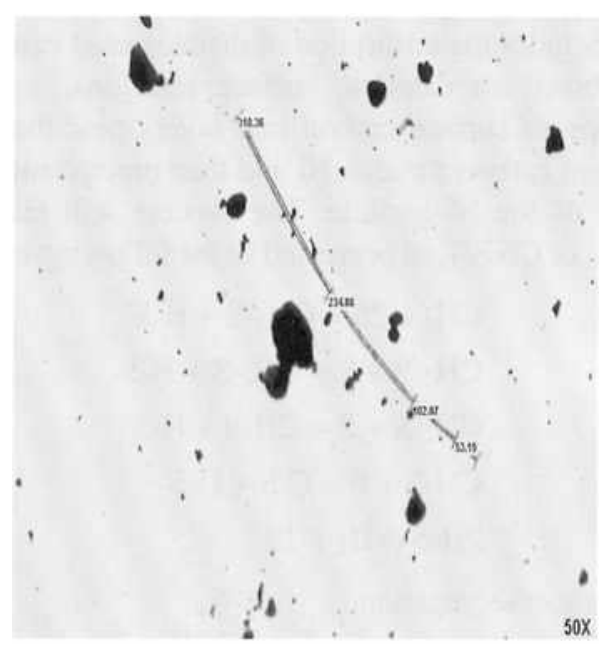

Figure \&. Presental ion of the dimension of the C-nanoluhes formed during $\mathrm{CH}_{\lrcorner}$decomposition reaclion.

observations are quite evident on the $\mathrm{K}$ doped samples: firstly the surface is very clean and no carbon formurion is ohserved during the 10 hours run for the reaction, possibly dee to formation of $\mathrm{Ni}: \mathrm{Cu}: \mathbf{K}$ surface sites which electronically modified the surface and secondly the life of the catalyst is considerably increased t.e. even after 30 hours continuous running the catalyst does not deactivate and the selectivity towards hydrogen production remains in the range of 18-20\% (Figure 9). We propose here that the 


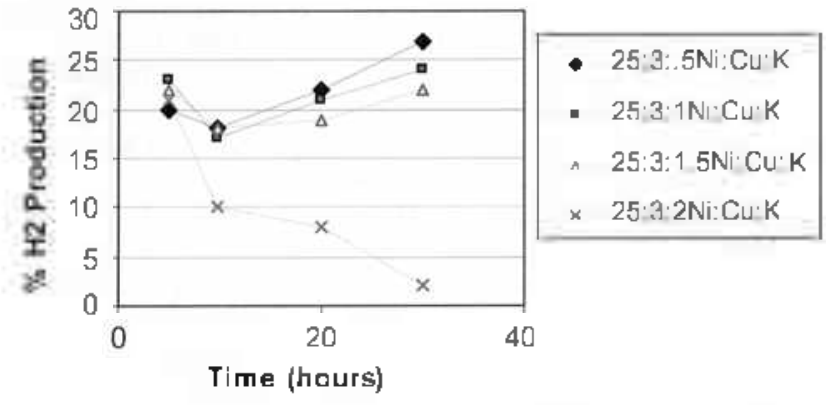

Figure 9. Eftect of $\mathrm{K}$ doping on hydrogen producrion (calalyst $\left.25 \% \mathrm{Ni} \cdot 3 \% \mathrm{Cu} / \mathrm{K}_{3}\right)$

polassium addition enhances the reverse reaction that is the gasitication of surface carhon increases, consequently the surface is not covered hy carbon. We also suggest that the addition of porassium suppresses the dissociation of methane resulting in the increase in life lime of the catalyst. Figure 9 represents the \% produclion of hydrogen is $\mathrm{K}$ doping, which clearly indicates the effect of $\mathrm{K}$ addition; the catalyst remains stable upto $1.5 \% \mathrm{~K}$ doping after that the stability decreases.

Effect of Copper Addition on the Prnduction of CN1s. On the $25 \%$ N1/Aluimna catalyst the yield of carbon is $181 \mathrm{~g}$ per $\mathrm{g}$ of $\mathrm{Ni}$. The addition of $3 \% \mathrm{Cu}$ increases the yield of carbon formalion. The highest carbon yield is on $25 \% \mathrm{Ni}$ : $3 \% \mathrm{Cu}$ doped samples which is $491 \mathrm{~g}$ per g of $\mathrm{Ni}$. When the Cu concentration increases from $3 \%$, the yield of carbon decreases. Taking the previous repouts into consideration, $\mathrm{Ni}$ $25 \%$ /Alumina is the most effective catalyst for merhane decomposition which produces $431 \mathrm{~g}$ carbon per $\mathrm{g}$ of $\mathrm{Ni} .{ }^{4}{ }^{4 / 3}$ The addition of copper and polassium has a marked effect on our system as presented below.

1. The formation CNTs of high purity

2. The produclion of pure hydrogen

3. The enhancement of catalyst stabilıly by K doping.

Catalyric performance of the catalyst system used in this study suggesis that the methane decomposition depends on the particle size of catalyst; the increase in $\mathrm{N}_{1}$ loading may

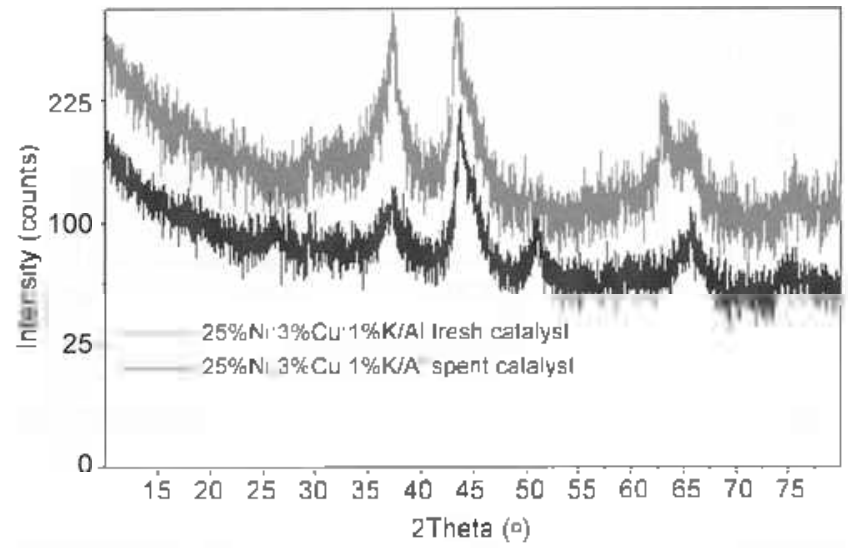

Figure 11. XRD analysis of $\mathrm{K}$ doped fresh and spen calalyst.

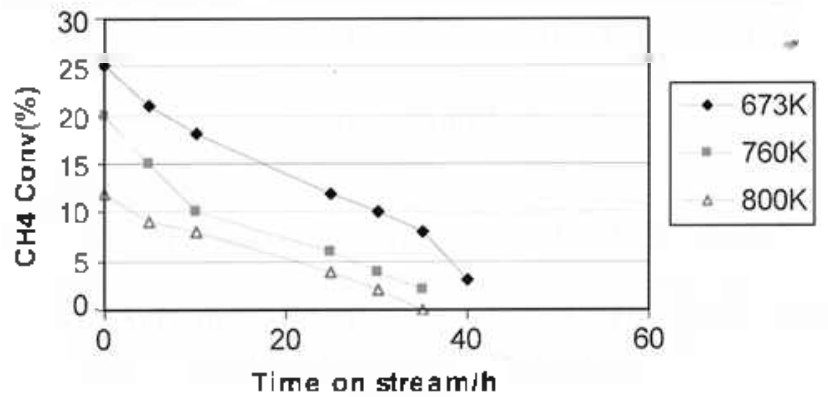

Figure 12 Kinelic curves of methane conversion in the methane decomposition over $25 \% \mathrm{Nu}_{1} 3 \% \mathrm{Cu} / \mathrm{Al}_{2} \mathrm{O}_{7}$ calalyst al different temperatures.

have an effect on the decomposition of $\mathrm{CH}_{\downarrow}$ hut the major share comes from the particle size coupled with C.u doping.

We also investigated the effect of reaction temperature on the catalytic performance of $25 \% \mathrm{Ni} .3 \% \mathrm{Cu} / \mathrm{A}$ laimna catalyst which was the most active catalyst for methane decomposition. Fugure 12 shows the kinetic curves of methane decomposition over our hest catalyst The temperalure was changed from $673 \mathrm{~K}$ in 760 and $820 \mathrm{~K}$. It is concluded from the figure that the deactivation rate of the catalyst decreases at lower temperalure. Figure 13 shows the change in carbon (a)

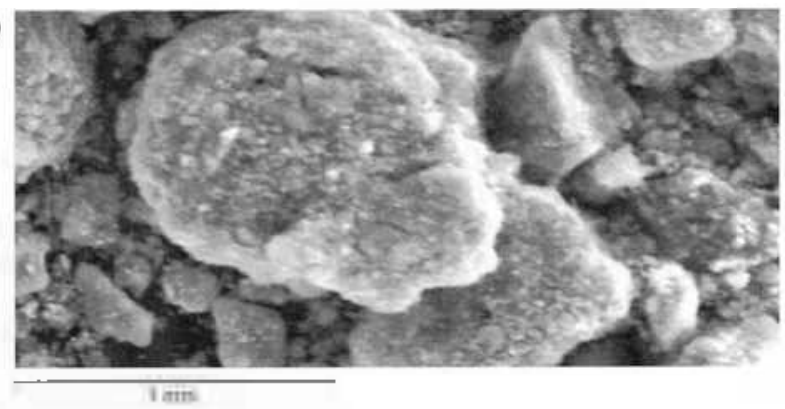

(b)

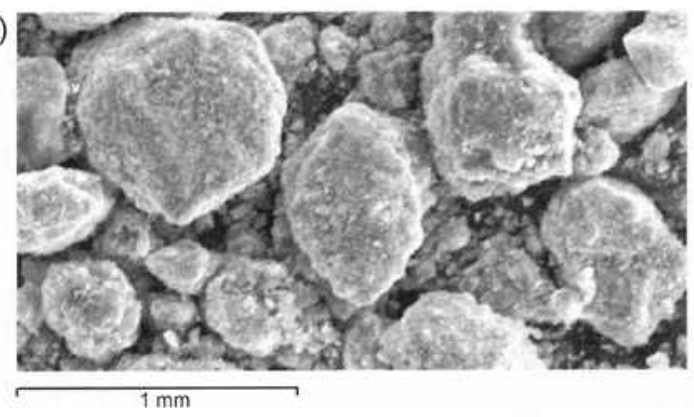

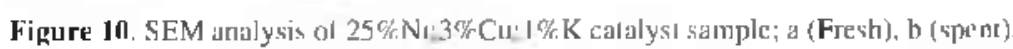

Tahle 7. EDX andysis of K dnped spent catalyst (contents in weight percent)

\begin{tabular}{cccccccccc}
\hline Catalyat Designaliour & & $\mathrm{C}$ & $\mathrm{O}$ & $\mathrm{Al}$ & $\mathrm{Cl}$ & $\mathrm{Ni}$ & $\mathrm{Cu}$ & $\mathrm{K}$ \\
\hline $25 \% \mathrm{~N}: 3 \% \mathrm{Cu}: 1 \% \mathrm{~K} / \mathrm{Al}$ & Mear & 00 & 42.1 & 26.8 & 2.7 & 23.6 & 3.9 & 0.91 \\
Spenı & $\mathrm{SD}$ & 00 & 3.15 & 2.35 & 0.55 & 3.98 & 0.50 & 0.02 \\
\hline
\end{tabular}




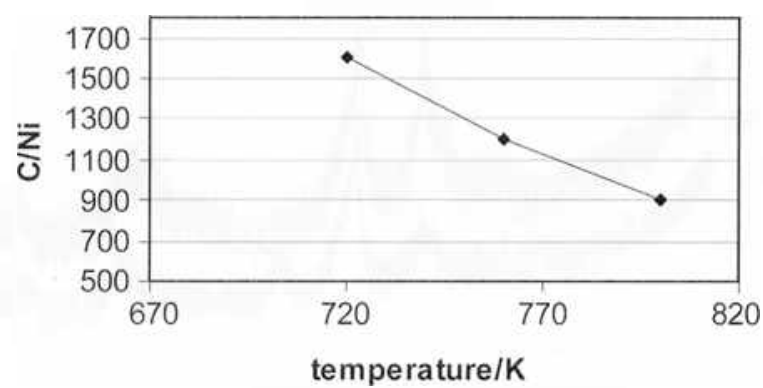

Figure 13 Change ju the $\mathrm{C} / \mathrm{Ni}$ as a function of reaclion lempeatue on $25 \% \mathrm{Ni} 3 \% \mathrm{Cu} / \mathrm{Al}$ caralyat

yicld ats a function of reaction temperature. As the reaction lemperature bocomes higher the $\mathrm{C} / \mathrm{Ni}$ value decreases This result indicales that lower temperature is needed in order to get high yicld of hydrogen and carbon.

\section{Canclusions}

We conclude as follows on the basis of results described:

I. Ni(25\%), Cu(3\%)/A] is one of the most effeclive catalysts for methane decomposition. The calalyst yields carbon luhes of higher length and widih with porous struclure at $673 \mathrm{~K}$.

2 All the copper doped calalysts pooduce bydrogen wishout the produclion of $\mathrm{CO}$ and $\mathrm{CO}_{2}$.

3. Catalyst stability is increased substantially with the $\mathbf{K}$ addition

4. The amoun of carbon formed during the reaction is related to the parlicle size and doping with coppes.

5. The yields of carbon and hydrogen decrease significantly with the increase in temperature.

6. The \%age Ni dispersion increases significantly with the modified method uad in this study.

Acknowledgement. The authors acknowledge the financial support of Higher Filucalion Commission. Pakistan for Ihis wolk through project No. 20-573/R \& D/(15/313.

\section{References}

I Hughes, 'I'. V: C'lamher, C R. I8R9. US Patem 405480.

2. Camben Fibors Filuments and Composilex: Figueiredo, J. L.; Bcrmardo, C A.; Baker. R T K.. Eds.; Kluwer Academic DoudrechuNowell, MA, 1990.

3. lshihara, T.: Miyashila, H.: Iseda, H: Takila, Y. Chen. Len 1995, 9.3, 11

4 Olsuka, K.: Kohalyalshi, S.: Talkenakä, S. Appl. Caral. A 20100. 190, 26I

5. Shiakhuldinow, S $\mathrm{K}$ : Avdeeva, I $\mathrm{R}$ : Gonchanva, $\mathrm{O}$. V: Kochubey. D. L: Novgorodov, B N: Plyasnva. L M Appl Cural A I9y5. 126, 125

6. Fimakova. M A.: Emakow. D. Yu.: Kuvshimov, G G: Plyasova, L. M. J. Caral. logy. 187,77.

7 Takenaka. S.: Ogihara. H. Yammanaka. I.: Otuska. K. Appl. Catol A 20101. 217. 101

8 Avdeeva, L B: Goncharova, () V: Kochuhey. I l.; Zaikovakii, V. L; Plyasova, L. N: Novgorodov. B N: Shaikhutdinov. Sh K Appl. Calal. A Iy以6, 141, 117.
2. Shariklutelinar, Sh. K.: Avdeeva, L. A.: Novgorodov, B. N.; 7ajkovskii, V. 1: Kochusey. D. I Caral. I ell. [997. 47. 35.

10) Fimakova, M A.: Finmakow, D Yu.: Kushinov, G C.: Plyasona, I . M. J. Caral. 1999, 187,77

11. Reshezenko, T. V.: Avdeeve, L. B.; lsmagilov, Z R.; Chuvilin, A 1.: Ushiknov. V. A. Apjol. Catal. A 2003. 247, 51.

I2 Takenaka, S; Kohayashi, S.: Ogihari, H.: Ostuka. K. J. Catal. 2003, 217,79

13. Li, J.: I_u, G: Li, K: Wang. W. I. Mol Cosm. A-Chrm. 20104. 221. 105

14. De Jong, K P.: Gues, J W Cahal. Rex: Sci, Eng. 2nll0, 42, 481.

15. Chambers, A.; Nemes. T.: Rodriguez. N. M: Bakes, R. T. K, J Phys. Chem B 1998. 102. 2251

I6 De Jong. K P: Geus, I. W. Chat Rev Sci. Eng 2nl01. 42.481

17 Otsuka, K: Ogihara, H: Takenaka, S Carhon 2003, 41.223

I8 Reshcienka, T. V.: Audeeva, L B.: Immagiloy, 7. R: Chuvilin. A. L.; Fenelonov. V. B. Caral. Todoy 2005. 102-103, I15

19. Conie. L. C.; Jemuler, S.; Kennelh. J. K. Lumgmir 2002. I8. I352.

20 Wang, C.: Gau, G; Gau, S.: Tang. C.; Bi, J. Caral. Leat. 2005. 101. 241

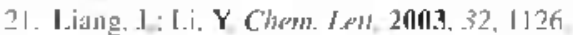

22 Liang. Z: 7hu, Y: Hu, X I. Phos Chem A 2010. IOR, .3488

23 Balandin. A. A In Adrances in Catalyws. Eley, D D : Frankenhurg. W. G; Komarewsky, V. I.; Weis\%, P. B. Eds; Acadenic Press: Orlandı, FL, 1958; Vo]. 10, p 96.

24. Kohozev. N. I Arto Physicuchim 1938. 9.805.

25. Dowden. [2 A. I. Chem. Suc Iontm 1950. 242

26 Simon. D: Rion, F. Sruf. Sci. 1994. 306. 459

27. Iang. N D: Holloway. S.: Norskow, ] K. Surf. Sri. 1987, 236. 403.

28. Hengaard. H. S.: Alstıup. [b.; Cloorkendorfl, lb.; U]lmamn, S.; Rosirup-Niclsen, J R : Noskov. J. K. I. Catril. I999 187. 238.

29) Ceyer. S 1: Yang. Q. Y.: I eem. M R: Beckelerie, I. D.: Johnson, A D Suld Stuf. Sci. Cutat. 1987. 36, S1

30 Rostrup-Nielsen. J R. I. Catal. 1987. 3.7, 173.

31. Rostrup-Nielsen, J. R. I. Coral. 1974. 31. 184.

32. Rostrup-Nielsen, J. R.; Christiansen, L. Appl Canal A: Con. 1995. 126. 781 .

3.7. Rosirup-Nielsen, I R.: Rak Hansen. J H: Aparicio, L. M. J. Jpu. Prinl. Hast 1997. 40. 366

.34 7han. N. Q: He, C N: Ding, J:; 7nu, T C: Qian, Z J. Shi. C S.; Du, X W: Li, J J: I.i. Y D /. Alloy: Compd 2007, 428, 79

35. Chai, S. Zein, S H S, Muhamed, A R Chen Phys Spll 2006. +26. 345 .

36. Inone. M.: A aji. K: Nag̣ayasu. Y.: Takane, K: Yugasaki, E. Adr: Sci Terh 20016 48.67

37 Suelves, 1: I azaro, M. I: Moliner. R. Fchegoyen. Y.: Polacios, $\mathbf{3}$ M Canat. Todan' 20106. //6. 271.

38 Rahman. M. S.; Croiset, F.; Hudgins, R R. Topics in Catmlsis 20106. 37. 137

39. Cullily. ค D. Elenents of $X$-ray Diffraction, $2^{\text {nd }}$ ed.: AddisonWesley: Menln Park. CA. 1978.

40 Roherlison. S D2: Menical, H. I): De Bass, J. H.; Kloez. S. C. lenkins, I. W. I. Cratal 1975, 37, 424

41 Rostıup-Nielson, I. R In Steani Refoming Caralysts: An In'esti-

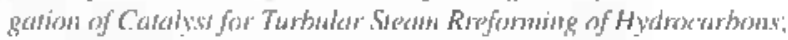
Tekujsk Forlag A/S: Copcuhagen, 1975

42. Thebes, M. L.: Billeı, J. H.: Van Dillen, A. J.: De Jong, K. P Crifrit Todor 2002, 76. 33.

4.3. Heımadi. K: Konya, 7. Siska, A: Kiss, I.; Oszkn. A: Naıy. J B: Kirivsi, I. Matel: Chrm. Phys 2003, 77, 536.

44 Park. C: Keane, M A. I. Calal. 20n4. 227, 386.

45. Emakova, D. Yu.; Ermakov, G G; Plyasova, L. M J. Caial 1999. 787,77 .

46. De Chen, Christunsen, K. O.; Fumundez. E. O.: Yu. Z; Toldal, A.: I.atome, N.; Monzon. A. Holmen, A. I. Cardi 2005, 229, 82, 